\title{
Sprawności receptywno-produktywne w kształceniu sprawności słuchania
}

\section{Umiejętność słuchania}

Słuchanie definiuje się jako proces poznawczy uruchamiający procesy myślowe, polegający na przypisywaniu odbieranym dźwiękom określonego znaczenia (Gronbeck et al. 2011: 57). Jest czynnością świadomą, wykonywaną aktywnie, ponieważ polega na postrzeganiu i uświadamianiu sobie tego, co się słyszy (zob. Seretny, Lipińska 2005: 138), innymi słowy — człowiek odbiera i identyfikuje jedynie te dźwięki, które są dla niego istotne, pozostałe zaś świadomie ignoruje (zob. Brześkiewicz 1999: 29). Podstawą słuchania jest prawidłowe słyszenie dźwięków - proces fizjologiczny polegający na ich odbieraniu, przetwarzaniu i przewodzeniu (zob. Adler et al. 2006: 181-185; Gronbeck et al. 2011: 56; Morreale, Spitzberg, Barge 2007: 208-209). Jeżeli narząd słuchu pozbawiony jest wad anatomicznych, funkcjonuje prawidłowo, układ nerwowy i odpowiednie struktury mózgu nie są zaburzone, a sam odbiór nie jest zakłócany czynnikami zewnętrznymi (hałas, niska częstotliwość dźwięków itp.), człowiek prawidłowo odbiera otaczające go dźwięki. Natomiast umiejętność słuchania różnego rodzaju komunikatów, w przeciwieństwie do słyszenia, nie jest wrodzona i wymaga doskonalenia szczegółowych sprawności percepcyjnych.

W literaturze przedmiotu można odnaleźć kilka koncepcji opisujących złożoność procesu odbioru komunikatów ustnych. Jedną z nich przedstawił Gerhart Lindner w 1976 roku. Według niego słuchowa percepcja tekstów przebiega w ramach siedmiu stadiów: kierowanie uwagi na bodźce akustyczne, rozpoznawanie sygnałów akustycznych jako znaków językowych, analiza wstępna (nastawiona na normy fonetyczne języka), odbiór zespołów znaków (zrozumienie sensu znaków), uzupetnienie znaków nie w pelni odbieranych (gdy znak językowy jest niekompletny, na przykład z powodu czynników zakłócających słuchanie), pojmowanie 
znaczenia wyrazów oraz dochodzenie do znaczenia wypowiedzi - uświadomienie sobie związków między jednostkami językowymi (zob. Lindner 1976: 107-114). W ten sposób Lindner wskazał procesy poznawcze zaangażowane w odbiór tekstu - począwszy od uwagi i koncentracji na dźwiękach (uruchomienia procesu słuchania), przez analizę i interpretację odebranych znaków oraz ich połączeń, skończywszy na przypisaniu im znaczenia.

Podobnego zdania jest Anna Polkowska, która twierdzi, że proces rozumienia tekstu uwarunkowany jest kilkoma analizatorami informacji lingwistycznej: fizycznych właściwości dźwięku (dekodowanie słuchowe), cech fonologicznych (dekodowanie leksykalne), cech semantycznych (dekodowanie semantyczne), cech syntaktycznych i morfologicznych (dekodowanie zdania) oraz tekstu (dekodowanie zawartości tekstu, intencji autora, rodzaju dyskursu itp.) (zob. Polkowska 1986: 281-282). Propozycja Polkowskiej, w przeciwieństwie do Lindnera, uwzględnia aspekt pragmatyczny wypowiedzi. Rozumienia nie utożsamia wyłącznie z rozpoznawaniem, identyfikacją znaków językowych (tworzywa tekstu) i przypisywaniem im znaczeń, ale również z interpretacją kontekstu pozatekstowego, społeczno-sytuacyjno-kulturowych uwarunkowań przekazu.

Takie podejście prezentuje też Maria Pąchalska, która uznaje, że rozumienie wypowiedzi składa się z trzech głównych typów procesów: przedjęzykowych (sygnały akustyczne zostają przekształcone na znaki językowe - fonemy), językowych (przekształcanie znaków na tekst - dekodowanie znaczeń) oraz pojęzykowych (interpretacja treści tekstu i jego uwarunkowań pragmatycznych) (zob. Pąchalska, Kaczmarek, Kropotov 2014: 443). Badaczka słuchanie utożsamia z odbiorem treści tekstu, identyfikacją jego formy językowej, kontekstu pozatekstowego, a także - w przypadku komunikatów ustnych - z rozpoznawaniem i rozumieniem warstwy segmentalnej i suprasegmentalnej wypowiedzi.

Nieco odmienny model przedstawili Anna Cutler oraz Charles Clifton Junior. Analizując proces słuchania, wyróżnili oni dekodowanie - wydobywanie dźwięków mowy z tła innych dźwięków, przekodowywanie na abstrakcyjny poziom reprezentacji; segmentację — wyodrębnianie w potoku mowy poszczególnych jej elementów, rozpoznawanie poszczególnych słów, fraz, wyrażeń, zwrotów; integracje - interpretację przekazu (Cutler, Clifton Jr. 1999: 124, cyt. za: Kurcz 2011: 78-79). Najistotniejsza dla tego modelu jest ostatnia faza, którą określa się jako etap włączania usłyszanej wypowiedzi do odpowiedniego dyskursu i analizowanie jej na jego tle (tekst traktuje się jako reprezentację dyskursu).

Przytoczone koncepcje przetwarzania tekstu ukazują przebieg słuchania w modelu dót-góra, który, jak uznaje glottodydaktyka, charakterystyczny jest dla mało doświadczonego odbiorcy lub osoby, która słucha trudnego dla niej tekstu (np. ze względu na brak wiedzy o przedmiocie wypowiedzi). Słuchacz odbiera dźwięki, różnicuje je, łączy w jednostki znaczeniowe (leksemy, syntagmy, zdania), a następnie na ich podstawie odkrywa sens całego komunikatu (zob. Gajewska 2011: 73). Natomiast dla tak zwanego kompetentnego słuchacza oraz, jak 
można przypuszczać, dla odbioru wypowiedzi w języku ojczystym charakterystyczny jest model rozumienia tekstu góra-dót, który opiera się na wykorzystywaniu wiedzy uprzedniej. Odbiorca w czasie percepcji wypowiedzi uruchamia schematy znaczeniowe, tworzy hipotezy na podstawie rozpoznanego kontekstu, testuje je i formułuje nowe (Gajewska 2011: 73). Proces ten uzależniony jest od kilku rodzajów wiedzy: wiedzy $i$ doświadczenia $w$ zakresie struktury komunikacji — znajomości typów dyskursu, planów, schematów, scenariuszy, sytuacji komunikacyjnych, nadawców, odbiorców, konwencji, norm kulturowych indywidualnych, subiektywnych, grupowych; wiedzy językowej — znajomości pojęć, ich nazw, reguł słowotwórczych, idiomów, kategorii gramatycznych itp.; wiedzy $o$ świecie - wiedzy logicznej, zdroworozsądkowej, potocznej, specjalistycznej; wyobrażeń, obrazów - reprezentacji w pamięci obrazowej niejęzykowej; wiedzy proceduralnej — warunkującej automatyzmy (zob. Dakowska 2007: 104-105). Obecnie uznaje się jednak, że odbiorca w czasie recepcji wypowiedzi (zarówno pisemnej, jak i ustnej) uruchamia jednocześnie oba procesy. Słuchacz wykorzystuje bowiem przetwarzanie tekstu góra-dót (top-down), aby uzupełnić braki w recepcji tekstu w modelu dót-góra (bottom-up) (Podpora-Polit 2012: 26). Cechy takiego odbioru wypowiedzi to symultaniczność przetwarzania różnego typu informacji (np. syntaktycznej, semantycznej, pragmatycznej), interakcyjność różnego rodzaju wiedzy, jej komponentów oraz etapów i poziomów przetwarzania, dwukierunkowość (przetwarzanie tekstu w ramach modelu góra-dót oraz dót-góra), a także selektywność (Kurcz, Polkowska 1990: 6; Dakowska 2007: 101-102).

$\mathrm{W}$ proces słuchowej percepcji wypowiedzi zaangażowanych jest kilka procesów myślowych. Ronald B. Adler, Lawrence B. Rosenfeld, Russell F. Proctor II, autorzy podręcznika Relacje interpersonalne. Proces porozumiewania się (Adler et al. 2006), są zdania, że słuchanie składa się z pięciu równolegle przebiegających procesów: słyszenia - odbioru fal dźwiękowych przez narządu słuchu, uczestniczenia - skupienia się na słuchanym tekście (uwadze, koncentracji) oraz selekcji informacji, zrozumienia — treści (kompetencji językowej) i kontekstu wypowiedzi (kompetencji komunikacyjnej i kulturowej), zapamiętania - odtwarzania usłyszanych informacji, reagowania - werbalnego lub/i niewerbalnego nadania informacji zwrotnej (Adler et al. 2006: 185-188). Pierwsze cztery etapy ściśle wiążą się z recepcją wypowiedzi (tak zwane procesy wewnętrzne), natomiast ostatni z nich ma charakter produktywny (tak zwany proces zewnętrzny). Zdaniem badaczy produktywny element percepcji słuchowej jest jej niezbędnym elementem w procesie komunikacyjnym, gdyż dzięki komunikatom zwrotnym nadawca tekstu wie, że jego wypowiedź została wysłuchana i zrozumiana.

Do tej pory nie wiadomo, czy percepcja w języku ojczystym i języku obcym przebiegają w identyczny sposób, angażują te same procesy i operacje myślowe. Niewątpliwie jednak słuchanie w języku obcym $\mathrm{i}$ języku ojczystym jest warunkowane przez wymienione między innymi przez Adlera i pozostałych badaczy kluczowe etapy słuchania: uczestniczenie, zrozumienie, zapamiętanie oraz reagowanie. Słucha- 
nie w języku obcym jest natomiast znacznie trudniejsze. Wynika to przede wszystkim z niedoskonałości opanowania tegoż języka (norm fonetyczno-fonologicznych, słownictwa, gramatyki itp.) oraz zdawkowej wiedzy o kulturowych uwarunkowaniach kontekstowych. Dlatego też Larry Vandergrift i Christine C.M. Goh podkreślają, że słuchanie w języku ojczystym to automatyczne przetwarzanie (automatic processing), gdyż ,cognitive processing occurs extremely rapidly, moving back and forth between top-down and bottom-up processes as required to achieve comprehension" (Vandergrift, Goh: 2012: 19). Z kolei słuchanie w języku obcym to tak zwane słuchanie kontrolowane (controlled processing), które ,involves conscious attention to and processing of elements in the speech stream" (Vandergrift, Goh 2012: 19). Dopiero z czasem, wraz z zdobyciem biegłości językowej, słuchanie w języku obcym staje się automatyczne (Vandergrift, Goh 2012: 19).

Można zatem uznać, że efektywne słuchanie zarówno w języku ojczystym, jak i obcym polega na aktywnej rekonstrukcji wypowiedzi nadawcy, nadaniu jej znaczenia w kontekście zdobytej wiedzy, własnego doświadczenia, innymi słowy przyswajaniu nowych informacji, sprawdzaniu ich w kontekście wiedzy uprzedniej, selekcji informacji (oddzielaniu treści ważnych od drugorzędnych, ich kategoryzowaniu), przewidywaniu tego, co za chwilę zostanie powiedziane, tak zwana antycypacja (zob. Roach, Wyatt 2005: 221), a także analizie i interpretacji wypowiedzi na tle odpowiedniego dyskursu (stosownych dyskursów). Słuchanie nie jest procesem biernym, lecz aktywnym. Aby doszło do efektywnej percepcji wypowiedzi, słuchacz uruchamia złożone procesy myślowe oraz tworzy wypowiedź lub/i w sposób niewerbalny przekazuje nadawcy tekstu komunikat świadczący o zrozumieniu wypowiedzi. W warunkach naturalnych proces słuchania związany jest zarówno ze sprawnościami receptywnymi (odbiór tekstu, jego zrozumienie, zapamiętanie), jak i produktywnymi (nadanie komunikatu zwrotnego).

\section{Sprawności receptywno-produktywne w edukacji szkolnej}

Praca nad słuchaniem w szkolnej edukacji obejmuje doskonalenie sprawności receptywnych (związanych z odbiorem wypowiedzi, jej analizą, interpretacją, oceną) oraz receptywno-produktywnych. Sprawności receptywne, jakie uczeń nabywa i doskonali na lekcjach języka ojczystego i obcego w ciągu całego cyklu kształcenia, to: rozumienie treści tekstu — dosłowne, interpretacyjne i krytyczne; analiza jego formy i struktury; rozpoznawanie komunikacyjnych uwarunkowań wypowiedzi oraz analiza i interpretacja jej dźwiękowej warstwy ${ }^{1}$. Z kolei spraw-

${ }^{1}$ Analizę sprawności receptywnych w edukacji szkolnej przedstawiłam na konferencji naukowej nt. uczenia języka ojczystego w czasach (po)nowoczesnych, zorganizowanej przez Zakład Polonistyki Stosowanej Uniwersytetu Opolskiego w dniu 16 maja 2016 roku w Opolu. 
ności receptywno-produktywne wiążą się z działaniami (zarówno językowymi, jak i niejęzykowym). Są to wszelkie działania uczniowskie niewerbalne/werbalne (ustne lub pisemne) powstałe na skutek wysłuchania tekstu, sprowadzające się do jego przekształcenia bądź tworzenia na jego podstawie innej wypowiedzi lub wyrażenia własnych emocji wywołanych przez percepcję słuchową za pomocą sygnałów niewerbalnych (np. drama, pantomima).

Doskonalenie słuchania w szkolnej rzeczywistości nigdy nie występuje samodzielnie, zawsze połączone jest z kształceniem innych umiejętności, zarówno w dydaktyce języków obcych, jak i języka rodzimego. W glottodydaktyce wyróżnia się cztery modele testowania słuchania: 1 . słuchanie + mówienie; 2 . słuchanie + pisanie; 3. słuchanie + czytanie + mówienie; 4 . słuchanie + czytanie + pisanie (zob. Lipińska 1994: 76). Wydaje się, że wypracowany w glottodydaktyce model testowania umiejętności słuchania odzwierciedla proces kształcenia percepcji słuchowej na lekcjach języka ojczystego i języka obcego. Doskonalenie percepcji słuchowej odbywa się albo tylko na tekście mówionym, albo na tekście mówionym i pisanym, gdy odbiór wypowiedzi jest wsparty bodźcami wzrokowymi. Natomiast sprawdzenie jakości słuchania dokonuje się za pośrednictwem mówienia bądź pisania - uczeń ustnie, pisemnie albo w sposób niewerbalny prezentuje stopień zrozumienia komunikatu. Ponieważ kształcenie słuchania odbywa się zadaniowo, do omówionych modeli dołącza się również instrukcję (zob. Lipińska 1994: 76), czyli pytanie lub polecenie, które może być przekazywane drogą foniczną albo graficzną. Doskonalenie odbioru tekstu mówionego składa się więc z trzech głównych etapów: instrukcji, słuchowej percepcji tekstu głównego i werbalnej/niewerbalnej reakcji. Dwa pierwsze wiążą się z odbiorem (zrozumieniem) polecenia lub/i pytania oraz tekstu przeznaczonego do analizy, zatem angażują sprawności receptywne, ostatni zaś składnik dotyczy reakcji na komunikat (aktywizuje sprawności produktywne).

W dalszej części artykułu skoncentruję się na omówieniu dwóch ${ }^{2}$ sprawności receptywno-produktywnych, które powinny być doskonalone na lekcjach języka ojczystego, a mianowicie: wyszukiwanie $i$ wykorzystywanie informacji, reagowanie na komunikaty, a także na możliwych sposobach ich kształcenia. Ponieważ sprawności te rozwija się w ramach nauki języka obcego (zob. między innymi ESOKJ), zaproponowane w niniejszym artykule techniki pracy w dużej mierze opierają się na wypracowanej w glottodydaktyce metodologii kształcenia słuchania.

${ }^{2}$ W szkolnej edukacji można również wyróżnić trzecią sprawność receptywno-produktywną, tj. działania na tekście. Jednak ze względu na ograniczenie objętości artykułu rezygnuję z jej omówienia. Działania na tekście szczegółowo omówili Jerzy Bartmiński i Stanisława Niebrzegowska-Bartmińska (zob. Bartmiński, Niebrzegowska-Bartmińska 2009; Niebrzegowska-Bartmińska 2014: 24-29). 


\subsection{Sprawność wyszukiwania i wykorzystywania informacji}

Sprawnością kluczową percepcji słuchowej (procesu selektywnego) jest wyszukiwanie i wykorzystywanie informacji. Korzystając z niej, słuchacz uruchamia zarówno procesy odbiorcze (percepcja tekstu, selekcja informacji), jak i nadawcze - wybrane elementy słuchanej wypowiedzi wykorzystuje do realizacji różnych celów. Sprawność ta w dużej mierze uzależniona jest od uwagi i koncentracji słuchacza. W związku z tym ćwiczenia nastawione na rozwój wyszukiwania i wykorzystywania informacji doskonalą najważniejsze dla percepcji słuchowej zdolności i umiejętności.

W ramach nauki języka obcego sprawność ta jest najczęściej doskonalona spośród pozostałych sprawności percepcyjnych. Wynika to ze specyfiki kształcenia umiejętności słuchania - jedynie przez wykonanie zadań werbalnych/niewerbalnych można zweryfikować poziom procesów myślowych ucznia. Dlatego podczas rozwijania tej sprawności najistotniejsze jest przywiązywanie dużej wagi do sposobów wykorzystania usłyszanych informacji. Jednym z nich, wydaje się, że najważniejszym z perspektywy funkcjonalnego nauczania, jest tworzenie notatek - sprawność niezbędna do zdobywania i poszerzania wiedzy w życiu codziennym i zawodowym.

Notowanie ze słuchu jest umiejętnością skomplikowaną, wymaga intensywnej uwagi i koncentracji na materiale dźwiękowym oraz opanowania sprawności selekcji informacji, dlatego też powinno być kształcone już od pierwszych lat edukacji szkolnej. W ramach nauki języka ojczystego warto zapoznać uczniów z różnymi technikami notowania, co pozwoliłoby im wybrać dla siebie najefektywniejszy sposób. Jak podkreśla między innymi Ricki Linksman, skuteczność metod redagowania notatek jest uzależniona od dominującej półkuli mózgu piszącego, mianowicie osoby z dominującą lewą półkulą notują zwykle w sposób linearny i sekwencyjny, z prawą zaś - tworzą mapy mentalne bądź piszą w kolumnach, by za pomocą notatek uchwycić ogólny (globalny) obraz zagadnienia (Linksman 2001: 223-242).

Techniki notowania, z którymi warto zapoznać uczniów, to między innymi:

- notatki linearne - notowanie usłyszanych informacji w kolejności, w jakiej pojawiają się one w słuchanym tekście;

— sporządzanie planu usłyszanej wypowiedzi — wypisanie kluczowych punktów, a następnie szczegółowych informacji, które je dookreślają;

- redagowanie notatek $\mathrm{w}$ dwóch kolumnach $\left(\mathrm{A}^{3}\right)$ - usłyszane informacje notowane są w prawej kolumnie, następnie po ich przeczytaniu, po lewej stronie, zapisuje się pytania odnoszące się do stworzonych notatek;

${ }^{3}$ Wersja A techniki redagowania notatek jest efektywna dla osób z dominującą lewą półkulą, zaś z wersji B w życiu codziennym korzystać będą przede wszystkim uczniowie z dominującą prawą półkulą mózgu (Linksman 2001: 228-231). 
— redagowanie notatek w dwóch kolumnach (B) — słuchając tekstu, po lewej stronie zapisuje się pytania, a następnie, po wysłuchaniu materiału dźwiękowego, udziela się na nie odpowiedzi;

- mapa umysłowa - diagram, w którym zaznacza się kluczowe treści, daje on globalny obraz wzajemnych związków i relacji zanotowanych informacji (Linksman 2001: 221-234; Geuenich et al. 2016: 169-172).

Doskonalenie redagowania notatek w różnych formach ma na celu nie tylko rozwój percepcji słuchowej, lecz także doskonalenie umiejętności uczenia się. Dlatego tak ważne jest zapoznanie uczniów z różnymi technikami notowania. Z zaproponowanych ćwiczeń można korzystać w ramach pracy nad słuchowym odbiorem różnych rodzajów tekstów: literackich, nieliterackich, audialnych, audiowizualnych oraz w momentach lekcyjnych, w których stosuje się metodę wykładu. Ta ostatnia forma pracy przeważa na wyższych etapach kształcenia: nauczyciel przed częścią zasadniczą lekcji przywołuje konteksty biograficzne, historyczne, literackie, filozoficzne itp., aby ukierunkować interpretację omawianego na zajęciach tekstu, a uczniowie mają za zadanie zapisać niezbędne informacje. Podobna sytuacja ma miejsce, gdy uczniowie wygłaszają referaty na zadany temat. Wydaje się, że podczas tego typu czynności warto wykorzystać różne techniki notowania, co zaktywizuje uczniów do słuchania, a co za tym idzie - zwiększy efektywność odbioru.

Na lekcjach języka ojczystego nauczyciel może wybrać inne sposoby wykorzystywania usłyszanych informacji. Wydaje się, że szczególną wartość mają następujące metody pracy:

1. Przewidywanie - ustne/pisemne dokończanie czytanego przez nauczyciela zdania/tekstu.

2. Opowiadanie — przedstawianie treści wysłuchanego tekstu z różnych punktów widzenia lub wymyślanie dalszego ciągu historii.

3. Wehikuł czasu - prowadzenie narracji w innej perspektywie czasowej, na przykład opowiadanie usłyszanej historii jako wspomnień po latach lub czyjąś przepowiednię (Komorowska 1984: 188-206; Komorowska 1999: 174-210; Lipińska 1994: 86-87; Seretny, Lipińska 2005: 150-154).

Pierwsza technika mocny nacisk kładzie na rozwój antycypacji, czyli przewidywania tego, co za chwilę może zostać powiedziane. Uznaje się, że jest to mechanizm, podczas którego następuje tworzenie hipotez, ich potwierdzanie bądź odrzucanie, dlatego też poziom antycypacji bezpośrednio przyczynia się do rozumienia wypowiedzi oraz ma wpływ na szybkość procesu przetwarzania tekstu (Dźwierzyńska 2001: 72-121). Stanowi podstawę rozumienia wypowiedzi w modelu góra-dót. Ćwiczenia nastawione na jej rozwój w sposób funkcjonalny przygotują więc ucznia do biegłej percepcji słuchowej w sytuacjach pozaszkolnych.

Pozostałe techniki z kolei kładą nacisk na transformację usłyszanego tekstu na poziomie komunikacyjnym i językowym. Zmiana nadawcy tekstu lub jego 
odbiorcy, a także czasu narracji to ćwiczenia weryfikujące poziom zrozumienia wypowiedzi oraz implikujące rozwój kompetencji komunikacyjnej i świadomości językowej. W związku z tym po transformacji tekstu i ,wykorzystaniu” go w innej formie uczniowie powinni dostrzec efekt dokonanych przez siebie zmian, to znaczy zauważyć, jak zmienił się tekst, jaki cel został osiągnięty, w jaki sposób wpłynęło to na odbiór wypowiedzi.

Wykorzystywanie informacji na lekcjach języka ojczystego może również zostać ściśle zintegrowane z rozwojem kompetencji gatunkowej. Usłyszane, wyselekcjonowane z słuchanego materiału językowego informacje mogą zostać funkcjonalnie użyte podczas tworzenia innego, własnego tekstu: dedykacji, zaproszenia, listu (e-maila), podania, CV, życiorysu, sprawozdania, recenzji, kartki z dziennika, pamiętnika, charakterystyki, opisu, opowiadania, rozprawki, instrukcji, przemówienia, wywiadu czy też reportażu (w zależności od etapu kształcenia). Wydaje się, że działania te urozmaicą proces kształcenia umiejętności pisania, gdyż w rzeczywistości szkolnej tworzone przez uczniów teksty zazwyczaj odnoszą się do tekstów literackich przekazywanych drogą pisemną. Wykorzystanie materiałów audialnych/audiowizualnych usprawni ponadto uwagę, koncentrację, selekcję informacji oraz sprawność tworzenia notatek.

Jedną z ciekawszych, ale i bardzo wymagających technik wykorzystania usłyszanych informacji jest „mozaikowe słuchanie” (jigsaw listening) - metoda wykorzystywana na lekcjach języka obcego przeważnie do pracy nad słuchaniem poznawczym, służącym zdobyciu informacji (zob. Kubiak 1996: 353-359). Technika ta wymaga podziału uczestników zajęć na kilka grup. Zadaniem każdej z nich jest słuchanie (w tym samym czasie) różnych fragmentów jednego tekstu lub kilku wypowiedzi powiązanych z sobą tematycznie. Następnie po percepcji materiału dźwiękowego uczniowie w dyskusji panelowej wymieniają się usłyszanymi informacjami i rekonstruują cały tekst bądź wykonują zadania wymagające pełnej znajomości treści (Kubiak 1996: 353). Niewątpliwie metoda ta jest dość skomplikowana pod względem organizacyjnym: nauczyciel musi dobrać kilka tekstów, które poruszają jeden - wybrany na daną jednostkę lekcyjną — temat, przygotować odpowiednią ilość sprzętu audiowizualnego oraz tak zagospodarować przestrzeń klasową, aby poszczególne grupy nie przeszkadzały sobie wzajemnie (warto jednak zaznaczyć, że całkowite wyeliminowanie przeszkód zewnętrznych nie jest możliwe i może ponadto pełnić funkcje dydaktyczne: uczniowie będą mieli okazje usprawniać zdolność uwagi i koncentracji w niekorzystnych warunkach). Mimo wymienionych przeszkód wydaje się, że organizacja mozaikowego słuchania jest możliwa w szkole, na przykład w pracowni multimedialnej (dyskusja panelowa może z kolei odbywać się w każdej klasie).

Zastosowanie omówionej techniki na lekcjach języka polskiego (szczególnie w liceum/technikum) do pracy nad krytycznym odbiorem tekstów audialnych lub audiowizualnych może doprowadzić do ciekawej dyskusji na tematy społeczno-kulturowe. Żeby mozaikowe słuchanie osiągnęło zamierzone efekty, nauczyciel 
musi postawić ciekawy, aktualny problem społeczny: Czy kultura wysoka jest ciągle potrzebna?, Co współcześnie oznacza słowo patriotyzm?, Polskie mity narodowe, Obraz kobiety/mężczyzny/rodziny w mediach, Jak poprawić sytuację młodych w naszym kraju? itp. Po sformułowaniu tematu zajęć uczniowie w grupach słuchają przygotowanych fragmentów różnego rodzaju wypowiedzi medialnych, a następnie podczas dyskusji panelowej dzielą się swoimi spostrzeżeniami, krytycznie oceniają wysłuchane komunikaty i wspólnie próbują rozwiązać wskazany problem lub omówić postawione zagadnienie.

Tego rodzaju zadania pozwalają kształcić istotne w komunikacji interpersonalnej i w życiu społecznym umiejętności, między innymi kompetentnego odbioru tekstów audialnych i audiowizualnych, poddawania ich krytycznej ocenie, formułowania wniosków na podstawie przeprowadzonej analizy, wyrażania własnej opinii na dany temat i jej argumentowania, uczestniczenia w dyskusji (przekonywania do własnego zdania, kontrargumentowania itp.) oraz pracy w grupach. Dlatego mimo trudności związanych z organizacją mozaikowego słuchania warto przynajmniej raz na każdym etapie kształcenia zorganizować tego typu ćwiczenie. Poza tym omówiona technika (w zależności od postawionego problemu do rozwiązania) może być wykorzystywana na lekcjach wychowawczych, historii, wiedzy o społeczeństwie, etyki, filozofii lub w ramach zajęć międzyprzedmiotowych.

\subsection{Sprawność reagowania na komunikaty}

Nie tylko odbiór tekstów audialnych weryfikuje kompetencje słuchacza, lecz także jego świadomy udział w komunikacji interpersonalnej. Ponieważ doskonalenie efektywnego słuchania utożsamia się przede wszystkim z umiejętnością percepcji tekstów kultury, lekcje języka polskiego mogą nie wyposażać uczniów w kompetencje komunikacyjne niezbędne do pełnienia funkcji słuchacza w kontaktach z drugą osobą. Oprócz opanowania sprawności elementarnych percepcji słuchowej wydaje się, że współczesna szkoła powinna przekazać uczniom wiedzę o roli odbiorcy i jego obowiązkach względem nadawcy tekstu, co można utożsamiać z wiedzą metakomunikacyjną. W jej skład wchodzi między innymi umiejętność przekazywania komunikatu zwrotnego.

Reakcje słuchacza można podzielić na dwie grupy — reakcje werbalne i niewerbalne, które w akcie odbioru komunikatu mogą wystąpić łącznie (zob. Adler et al. 2006: 188-205). W pierwszej grupie wyróżnia się: zadawanie pytań, parafrazowanie, wyrażanie empatii (np.: To naprawdę było tragiczne!), wspieranie nadawcy (np.: Masz rację, Twoja praca jest bardzo ciężka), analizowanie i interpretowanie wypowiedzi nadawcy (np.: Wydaje mi się, że...), ocenianie komunikatu lub/i zachowania nadawcy (np.: Twój pomyst jest niezwykle interesujący) oraz rady (np.: Moim zdaniem powinnaś...). Z kolei do reakcji niewerbalnych, które charakterystyczne są dla „słuchania w milczeniu” (zob. Adler et al. 2006: 189), 
zalicza się między innymi: utrzymywanie kontaktu wzrokowego, ruchy głową, mimikę twarzy, gestykulację i postawę ciała.

Dzięki reakcjom słuchacza nadawca może mieć pewność, że jego wypowiedź została usłyszana i zinterpretowana, a co za tym idzie - odbiorca tekstu zaangażował się w jego percepcję. Zatem reagowanie na przekaz drugiego człowieka nie tylko świadczy o wysokiej kompetencji odbioru słuchowego, lecz także o słuchaczu, jego kulturze, wychowaniu, stosunku do nadawcy i jego wypowiedzi. Nauczyciel w ramach lekcji języka polskiego powinien więc zapoznać uczniów z typami reakcji, ich funkcjami i efektami komunikacyjnymi, jakie wywołują uznaje się bowiem, że niektóre komunikaty zwrotne są nieoceniające, jak pytania, inne zaś wartościują usłyszane wiadomości bądź nadawcę wypowiedzi: rady, komunikaty oceniające bądź analizujące (zob. Adler et al. 2006: 188-205).

Poznaniu typów reakcji mogą służyć teksty audiowizualne, różnego rodzaju rozmowy, dyskusje, debaty, wywiady prezentowane w mediach, fragmenty filmów, spektakli itp., w których możliwe jest zaobserwowanie nie tylko werbalnych komunikatów zwrotnych, ale także niewerbalnych. Nauczyciel przed odtworzeniem nagrań powinien ukierunkować uwagę uczniów na zachowania interlokutorów, a następnie, po wysłuchaniu materiału dźwiękowego, przeprowadzić rozmowę, w której uczestnicy zajęć będą oceniali poziom umiejętności słuchania uczestników rozmowy (Czy rozmówcy słuchają siebie nawzajem? Co o tym świadczy?) oraz jakość konwersacji (W jakim stopniu kompetentny/nieumiejętny odbiór tekstu wpływa na poziom dyskusji?). Kolejnym krokiem może być przekazanie uczniom informacji o typach komunikatów zwrotnych i ponowne obejrzenie nagrania (tego samego bądź innego - w zależności, czy adresaci ćwiczeń zauważyli wszystkie rodzaje reakcji), w czasie którego uczniowie będą rozpoznawać sposoby reagowania zastosowane przez rozmówców, określać ich funkcję (Czemu służyły?) oraz efekt komunikacyjny (Co spowodowały? Jak wpłynęły na nadawcę i jego następną wypowiedź? Jaki wyrażały stosunek odbiorcy do rozmówcy i jego tekstu?). Tego typu działania mogą być interesujące dla uczniów, ponadto pozwolą im uświadomić, jak ważne i jak trudne jest efektywne słuchanie w komunikacji interpersonalnej. Co więcej, podczas oglądania i analizowania dyskusji, debat medialnych można zwrócić uwagę na czynniki, które zaburzają efektywną percepcję wypowiedzi, ukierunkować uczniów na najczęściej występujące przeszkody - fizyczne: środowisko, hałas, cechy i zachowania mówcy/słuchacza; psychiczne: tempo mówienia, przeciążenie wiadomościami, ich złożoność; interakcyjne: agresja słowna, różnice kulturowe (Morreale, Spitzberg, Barge 2007: 220-226).

Poza analitycznymi zadaniami warto organizować ćwiczenia, w których uczestnicy zajęć będą korzystali z poznanych typów reakcji, czemu może służyć układanie dialogów zgodnie z określonymi przez nauczyciela wyznacznikami sytuacji komunikacyjnej (temat rozmowy, miejsce, czas, uczestnicy, ich relacje itp.), a następnie ich zaprezentowanie na forum klasy. Pozwoli to doskonalić sprawność reagowania na komunikaty, rozwijać wiedzę na temat zasad grzeczności języko- 
wej oraz usprawniać zdolność operowania własnym głosem. Zadania te mogą mieć albo charakter improwizacyjny, gdzie umiejętność słuchania będzie ściśle łączona z mówieniem, albo zaplanowany — uczestnicy zajęć najpierw zapiszą swoje wypowiedzi, a następnie je odczytają. Po wystąpieniach uczniów niezbędnym elementem jest analiza prezentowanych scenek. Wydaje się, że bardziej wartościowe okażą się dialogi prezentowane bez żadnego przygotowania. Wówczas nauczyciel może również zwrócić uwagę uczniów na jakość rozmowy, sprawność wzajemnego słuchania lub jej brak, stosunek odbiorcy do usłyszanych wypowiedzi oraz na język interlokutorów (Czy jest odpowiedni do sytuacji? Jakich zwrotów do adresata używają? Jakich reakcji słownych? Czy jest to język poprawny pod względem ortofonicznym, składniowym itp.? Jaki styl reprezentuje?). Odpowiednio dobrane pytania mogą przyczynić się do poszerzenia wiedzy językowej uczniów, a co za tym idzie - w nietradycyjny sposób przygotować ich do egzaminu dojrzałości, szczególnie części ustnej. Podobne ćwiczenia można organizować na przykład w ramach symulowania próbnych rozmów kwalifikacyjnych w związku z kształceniem redagowania CV i listu motywacyjnego, na których poddawana ocenie będzie zarówno umiejętność generacji wypowiedzi, jak i jej percepcji.

Wiedzę o reakcjach na komunikaty można również funkcjonalnie wykorzystać podczas tworzenia tekstów, na przykład doskonalenia pisania opowiadania z dialogiem. Wówczas funkcjonalizacja zdobytych wiadomości odbywać się będzie w ciekawy sposób, wzbogaci tworzone teksty i zarazem zweryfikuje świadomość uczestników zajęć odnośnie do typów komunikatów zwrotnych, ich funkcji i efektów. Ćwiczenia te można zacząć już organizować na drugim etapie edukacyjnym, gdzie uczniowie uczą się zapisywać rozmowę, zapoznają się z zasadami grzeczności językowej i uczestniczą w różnego rodzaju zabawach parateatralnych.

\section{Cele rozwijania sprawności receptywno-produktywnych}

Reasumując, sprawności receptywno-produktywne stanowią niezwykle ważny element kształcenia percepcji słuchowej w szkole. W przeciwieństwie do umiejętności receptywnych (skupiających się wyłącznie na odbiorze — rozumieniu, analizie i interpretacji wypowiedzi) nastawione są przede wszystkim na działania językowe zmotywowane recepcją tekstu. W ramach nauki języka ojczystego sprawnościom receptywno-produktywnym można przypisać następujące cele edukacyjne:

1. W zakresie wyszukiwania i wykorzystywania informacji uczeń:

- selekcjonuje usłyszane informacje, klasyfikuje je i hierarchizuje,

- wykorzystuje usłyszane informacje w praktyce, przekazuje je partnerowi komunikacji, wykorzystuje do tworzenia innych tekstów i uzasadnienia swojego stanowiska,

— umiejętnie, korzystając z różnych technik, notuje usłyszane informacje. 
2. W zakresie reagowania na komunikaty uczeń:

— zna podstawowe typy reakcji zwrotnych, jest świadomy ich celów i efektów komunikacyjnych,

- świadomie uczestniczy w rozmowie, wykorzystuje różne strategie podtrzymania rozmowy, między innymi zadaje pytania nadawcy tekstu, parafrazuje jego wypowiedź,

- uważnie, z empatią słucha partnera komunikacji, formułuje rady,

— odznacza się postawą krytyczną wobec usłyszanego tekstu, obiektywnie ocenia wypowiedź nadawcy, precyzyjnie wyraża swoje zastrzeżenia i wątpliwości, zgodnie z etykietą prosi o wyjaśnienie niezrozumiałych faktów.

Realizacja zaproponowanych celów przez cały cykl kształcenia, organizowanie różnorodnych zadań i wykorzystywanie rozmaitych tekstów pozwoli skuteczniej kształcić umiejętność efektywnego słuchania. Uczniowie będą mieli możliwość rozwijania różnych rodzajów percepcji słuchowej (poznawczej, krytycznej i empatycznej), zapoznania się z specyfiką słuchowego odbioru różnego typu tekstów i obowiązkami odbiorcy względem nadawcy w przestrzeni komunikacyjnej. Doskonalenie słuchania zostanie ściśle powiązane z rozwojem kompetencji komunikacyjnej, przez co będzie odpowiadać na potrzeby współczesności - postawi w centrum jedne z najczęściej wykorzystywanych umiejętności w życiu codziennym.

\section{Bibliografia}

Adler R.B. et al., 2006, Relacje interpersonalne. Proces porozumiewania się, Poznań.

Bartmiński J., Niebrzegowska-Bartmińska S., 2009, Tekstologia, Warszawa.

Brześkiewicz Z.W., 1996, Superstuchanie. Jak stuchać i być stuchanym, Warszawa.

Cutler C. Jr., 1999, Comprehending spoken language. A blueprint of the listener, [w:] The Neurocognition of Language, red. C.M. Brown, P. Hogoort, Oxford, s. 123-166.

Dakowska M., 2007, Psycholingwistyczne podstawy dydaktyki języków obcych, Warszawa.

Dźwierzyńska E., 2001, Antycypacja w procesie ksztaltowania sprawności rozumienia mowy obcojęzycznej ze stuchu, Rzeszów.

ESOKJ, Europejski system opisu kształcenia językowego. Uczenie się, nauczanie, ocenianie, 2003, przeł. W. Martyniuk, Warszawa.

Gajewska E., 2011, Techniki nauczania języka obcego, Tarnów.

Geuenich B. et al., 2016, Techniki uczenia się. Jak efektywnie przyswajać wiedzę, przeł. U. Szymanderska, S. Lipnicki, Łódź.

Gronbeck B.E. et al., 2011, Zasady komunikacji werbalnej, Poznań.

Komorowska H., 1984, Testy w nauczaniu języków obcych, Warszawa.

Komorowska H., 1999, Metodyka nauczania języków obcych, Warszawa.

Kubiak B., 1996, Jigsaw Listening - stuchanie „mozaikowe”, „Języki Obce w Szkole”, nr 4, s. 353-359.

Kurcz I., 2011, Charakterystyka kompetencji językowej - wytwarzanie i percepcja mowy, [w:] Język jako przedmiot badań psychologicznych. Psycholingwistyka ogólna i neurolingwistyka, red. I. Kurcz, H. Okuniewska, Warszawa, s. 66-79. 
Kurcz I., Polkowska A., 1990, Interakcyjne i autonomiczne przetwarzanie informacji językowych: na przykładzie procesu rozumienia tekstu czytanego na głos, Wrocław.

Lindner G., 1976, Podstawy audiologii pedagogicznej, przeł. J. Wierzchowski, Warszawa.

Linksman R., 2001, W jaki sposób szybko się uczyć, przeł. J. Korpatny, Warszawa.

Lipińska E., 1994, Stuchanie - sprawność zaniedbywana, „Przegląd Polonijny”, z. 4, s. 75-89.

Morreale S.P., Spitzberg B.H., Barge J.K., 2007, Komunikacja między ludżmi. Motywacja, wiedza i umiejętności, Warszawa.

Niebrzegowska-Bartmińska S., 2014, Działania na tekście, „Polonistyka”, nr 1, s. 24-29.

Pąchalska M., Kaczmarek B.L.J., Kropotov J.D., 2014, Neuropsychologia kliniczna. Od teorii do praktyki, Warszawa.

Podpora-Polit E., 2012, Testowanie sprawności receptywnych $w$ standaryzowanych testach języka angielskiego i niemieckiego — próba analizy porównawczej, http://www.sbc.katowice.pl/Content/93272/doktorat3334.pdf [dostęp: 21.11.2016].

Polkowska A., 1986, Interakcyjny model rozumienia tekstu w świetle badań nad polskimi i angielskimi tekstami różnej trudności, [w:] Wiedza a język, t. 1. Ogólna psychologia języka i neurolingwistyka, red. I. Kurcz, J. Bobryk, D. Kądzielawa, Wrocław, s. 281-296.

Roach C.A., Wyatt N.J., 2009, Stuchanie i proces retoryczny, [w:] Mosty zamiast murów. Podręcznik komunikacji interpersonalnej, red. J. Stewart, Warszawa, s. 218-224.

Seretny A., Lipińska E., 2005, ABC metodyki nauczania języka polskiego jako obcego, Kraków.

Vandergrift L., Goh Ch.C.M., 2012, Teaching and Learning Second Language Listening, New York. 